\title{
A theological perspective on human dignity, equality and freedom
}

\author{
Author: \\ Nico Vorster ${ }^{1}$ \\ Affiliation: \\ ${ }^{1}$ Faculty of Theology, \\ North-West University, \\ South Africa \\ Correspondence to: \\ Nico Vorster \\ Email: \\ nico.vorster@nwu.ac.za \\ Postal address: \\ Internal Box 147, Faculty \\ of Theology, North-West \\ University, Potchefstroom \\ Campus, Private Bag X6001, \\ Potchefstroom 2520, \\ South Africa \\ Dates: \\ Received: 03 Feb. 2012 \\ Accepted: 23 Aug. 2012 \\ Published: 04 Oct. 2012 \\ How to cite this article: \\ Vorster, N., 2012, 'A \\ theological perspective on \\ human dignity, equality and \\ freedom', Verbum et Ecclesia \\ 33(1), Art. \#719, 6 pages. \\ http://dx.doi.org/10.4102/ \\ ve.v33i1.719
}

Human dignity has proven to be a vague term in liberal rights discourse because of its broad range. This article attempted to provide a Christian definition of human dignity that is helpful in resolving tensions between equality and freedom. Firstly, it addressed the question of whether religious understandings of human dignity ought to be considered in the public domain. Secondly, it provided a theological perspective on dignity, equality and freedom and, lastly, it considered the special contribution that a Christian concept of dignity, equality and freedom can make to the rights discourse.

\section{Introduction}

Freedom and equality often seem to be irreconcilable values. Freedom, in essence, demands personal autonomy, whereas equality demands positive entitlements to individuals and groups of people. Such conflicting aims are destined to collide with each other. The South African Constitution (Republic of South Africa 1996) purposively employs the value of human dignity to reconcile the conflicting interests of freedom and equality. In its preamble it namely states that the Republic of South Africa is founded upon human dignity, whilst Article 37 describes human dignity as inviolable. In various judgements, the South African Constitutional Court described human dignity as the 'source of all other rights' (cf. Chaskalson 2000:196). Although the effort to employ human dignity explicitly as an interpretative tool in a legal document must be commended, human dignity has proven to be a vague term in liberal human rights discourse. The reason is that human dignity seems to allow for all sorts of rights because of its broad range; for instance, it is often used to define illegitimate rights such as rights to pleasure, luxury, language purity, euthanasia, et cetera. Witte (2006) rightly states:

human dignity must be assigned some limits if it is to remain a sturdy foundation for the edifice of human rights. Not every good ought to become part of human dignity, and not every aspiration ought to become subject to human rights vindication. (pp. 47-48)

This article will attempt to provide a Christian definition of human dignity that is sufficiently confined, but is also able to reconcile the conflicting interests of freedom and equality. The first question to be answered, though, is whether religious concepts of human dignity ought to be considered part of the public domain at all.

\section{Religious concepts of human dignity and the public domain}

Adherents of the liberal contractarian tradition of natural rights see the inherent dignity of human beings as residing in the possession of equal and inalienable rights. This tradition developed through thinkers such as Locke, Rousseau, Kant and apologists for the American Revolution, to such contemporary political philosophers as Robert Nozick and John Rawls ( $\mathrm{O}^{\prime}$ Donovan 2010:119). The inherent dignity of the individual is seen in this tradition as residing in his or her moral freedom, understood as the agent's ownership and rational government of his or her own acts and of his or her spiritual and physical resources (O' Donovan 2010:119). Thus understood, the individual's moral freedom is the original right of self-disposal through rational choice, defensible against the whole world and all other individuals ( $\mathrm{O}^{\prime}$ Donovan 2010:119).

The problem with the abovementioned understanding of human dignity is that dignity is seen as an immanent self-standing structure based upon self-consciousness, reason, moral freedom and social relatedness. What these thinkers do not take into account is that their view rests upon a certain view of 'being', a certain ontology which contains values that belong to the realm of the non-perceptible. The traditional liberal notion of a social contract, which proceeds from the independent non-moral values of each to a general canon for all, is simply naive. There is namely no such thing as values that are based upon pure reason and non-moral principles. Stated differently: no social science can exist on its own. Sociology, for instance, employs a certain morality when it states that society can be improved if certain scientific tools are used to order society. The moral premise is that an instrumental kind of rationality is acceptable. 
Yet, in pre-modern times, such an instrumental view of rationality would have been seen as immoral because it disturbs the natural order of things. Every social science or theory is embedded in some kind of moral metanarrative that is non-perceptible.

Classic liberalism contains various ontological assumptions and constructions based upon non-perceptible values. Firstly, it begins with human persons as individuals. The ontological essence of the human person is defined as 'will', 'capacity' or the impulse to 'self-interest'. A certain understanding of 'being' is thus promulgated which is not based on natural perceptible grounds but on non-perceptible value-driven considerations. However, there is no factual proof that humans are primarily self-interested beings. A deliberate ethical choice is, furthermore, made not to take the essence of the collective as premise, but to root rights theory in an individualistic account of the 'will'. Again, this choice is based upon a non-perceptible value-driven moral choice. 'Will' is an ontological concept. Liberal discourse presupposes the isolated self-conserving individual, whilst the social is artificially deduced from the interrelationships of such individuals.

A second value-driven ontological construction is made by relating autonomy to dominium over property. One's selfidentity is related to the rational and ethical management of one's property. The individual possesses the power to do as they like with their property, such that property rights are 'as much a right of exchange as the right to make use of the property' (cf. Milbank 2006:13). Fundamental to the notion of dominium is the ontological understanding of the 'being' or 'essence' of society as existing of free and equal individuals who possess an inherent right to non-interference and therefore can make claims and counter-claims. However, the values of liberty and equality are not based upon fact; they are non-perceptible values. People are not, empirically speaking, born free or equal but are born with different abilities and characteristics, within different and often very unequal social settings.

A third value-driven ontological construction is the notion of absolute sovereignty. According to classic liberalism, claims and counter-claims of individuals need to be adjudicated through an undisputed sovereign power which operates in a secular sphere. Again, this view of power is not derived from empirical reality or fact, but from a philosophically constructed view of society as a contractual entity. Because natural rights theory is unable to solve the problem of spontaneous human collaboration, it is forced to resort to artificial theories of original contract. However, as soon as non-perceptible values enter the equation, we start speaking in transcendental categories.

The basic theoretical problem in the classic-liberal understanding of rights is that they do not seem to realise that any concept of human rights inevitably rests upon notions of the nature of 'being' and values that are non-perceptible. There is simply no human rights theory that can be built purely upon reason and factual non-moral values. Human rights discourse belongs to the realm of moral valuation. Furthermore, as mentioned above, as soon as we speak about non-perceptible values, transcendental categories come into play. Because human rights discourse belongs to the same realm of non-perceptible 'valuation', theological understandings of human dignity and rights are perfectly legitimate narratives in the public domain. The reason and faith, fact and value distinctions of modernity cannot be upheld, because any normative, ethical or anthropological concept contains a religious or quasi-religious ground motif. In fact, rights discourse developed to some extent from religious discourse. Stackhouse (2006:33) rightly states that intellectual honesty demands recognition of the fact that what passes as 'secular Western' principles of rights developed nowhere else but out of key strands of the biblically rooted religions. The Western notion of rights was largely created by the fusion of Jewish-Christian monotheism, natural law theory, humanism, and the Enlightenment's political conceptions. Van der Ven, Dreyer and Pieterse (2004:80-96) also stress the error in seeing faith as in opposition to human rights. According to them (2004:11), much of Western moral thinking can be traced back to the Judeo-Christian tradition and Graeco-Roman philosophy. In order to utilise the concept of human dignity as a source of fundamental rights, the religious roots of the concept must, in my view, be rediscovered.

One important caveat, however, must be stated. Religions should translate their concepts of dignity into language that can be juridically applied and universally accepted. It thus ought to be explicated in such a manner that the acceptance of these religious concepts of dignity in the public domain does not demand a prior conversion to a particular faith.

I will now proceed to provide a Christian view of human dignity that explicitly employs transcendental religious concepts to solve conflicts between liberty and equality. My hypothesis is that this approach could be more successful than classic-libertarian approaches, because the human will can never find a 'resting place' in any of its natural intentions or actions. The immanent requires the transcendent, because non-perceptible valuation is an inescapable part of reality.

\section{A Christian perspective on dignity, equality and freedom}

For the sake of conciseness, I will not attempt to engage here in extensive technical exegesis of various passages, but will rather attempt to give a wider, systematised perspective on human dignity based upon recurring biblical themes.

Theologically speaking, humankind is God's property. Humans belong to their Creator, for they are his workmanship and are obliged to do his will. Persons do not belong to other persons and therefore have a God-given property in their own person. This entails that persons are entitled to God-given rights that protect their basic properties; it also implies the correlating duty to respect similar properties of other individuals. 
The human person's most basic property is the right to dignity. Christian ethicists have, at least since the time of Ambrose of Milan, grounded their understanding of human dignity in the biblical concept of the imago Dei, a concept which indicates the basic unity of humankind. According to this view, human dignity entails that human beings are entitled to be treated as worthy of respect and concern, because they stand in a special relationship to God. Although explicit references to the human being as the image of God are found in the Old Testament only in Priestly material, it is of enormous importance for the Old Testament's understanding of anthropology because it is an expression of that which is most distinctive in the human and in his or her relation to God (cf. Harland 1996:208). The New Testament also expands this concept, giving it Christological content. In Pauline literature, Christ is portrayed as the perfect image of God and as the destiny of humankind (cf. 2 Cor 3:18; 4:14; Eph 4:24; Col 3:10). The human's image of God is related in these passages to the ability of the human to follow Christ and to reflect divine virtues, such as knowledge, holiness and righteousness.

Van der Ven et al. (2004:155) indicate that the notion of being created in the image of God originated in ancient Egypt and Assyria. However, these cultures only regarded the king as created in the image of God. Eckart Otto $(1999,2002)$ did important research in this regard. According to Otto $(1999,2002: 171-174)$ the king was seen in ancient Assyria as the earthly instrument of the creator-god Aššur. Whilst the creator-god above was involved in the cosmological struggle against chaos, the earthly king who was regarded as the representative of Aššur was the ultimate protector on earth. There were thus no limits to the political power of the king. The Priestly narrative clearly subverts this view by ascribing createdness in the image of God to all human beings. Through the imago Dei, it assigns to human beings a special place in God's creation by depicting them as God's representatives on earth. It expresses the human person's creational status in relation to God, his or her fellow human beings and the earth. The imago Dei refers specifically to those special dimensions of human nature that elevate humans above the animal plain, such as the ability to personhood, self-awareness, selfdetermination and the ability to respond to God (Anderson 1994:108). In contrast to animals, the human being is created with certain structural possibilities, so that he or she can indirectly manifest and reflect the virtues of God on earth.

The right to life, autonomy and equal respect are, in my view, three of the most basic components of a theological concept of human dignity. Without life, no person can possess dignity or exercise rights. The Priestly material in Genesis emphasises that life has a divine origin and that God is the sustainer of all life (cf. Gen 2:7). ${ }^{1}$ Because God is the source of life, he is insulted when human life is destroyed, because his communion with the human being is obliterated. Genesis 9:6 specifically prohibits manslaughter, because the

1.This emphasis on God as origin of life coincides with the Priestly project to fill in the space of time from the first man to historic times with genealogical chronologies (cf. Van Seters 1997:28). human being is a representative of God. It thereby places life beyond the reach of other values. Death means separation from God, who is the source of life and joy, and therefore death obliterates the status of dignity that God grants human persons. This notion is illustrated in Pentateuchal passages, where dead things represent uncleanliness and are excluded from service to God (cf. Lv 22:4, 8).

So important is the right to life that it is extensively protected in the Torah, which prohibits both intentional and unintentional killing. Whenever a person is killed, God is dispossessed. Reconciliation with God is therefore necessary even in the case of an unintentional killing (cf. Nm 35:33). Several Pentateuchal laws protect the right to life in a positive sense, by prohibiting negligent forms of behaviour that could endanger life, simultaneously making the handing down of life through the generations possible (cf. Ex 22:28, 29; Lv 19:16; Dt 22:8; 24:16; 19:1-13).

A central message of the New Testament is that Christ brings life (Jn 14:6). God's act of redemption in the life, death and resurrection of Christ begins to actualise not only God's saving purpose made manifest to Israel, but also the intention inherent in the creation from the beginning (cf. Anderson 1994:17). Through his resurrection He conquers death and suffering and reveals human destiny. Life must therefore be valued as a central part of the divine purpose for God's creation.

Vogel et al. (2007:25) rightly states that the right to life, in the Christian perspective, contains a negative dimension, in that it is a right of defence against arbitrary killing, but it is also positive in that it supposes a right to development. This right to development can be theologically substantiated on the covenantal notion that God is a God of generations for whom the handing down of life through the generations is important. The right of development presupposes a willingness to hand down life, on which the relationship between generations, the future of a nation and the further development of culture are utterly dependent. It is important that present-day political decisions must take seriously the life opportunities of future generations, especially with regard to the burden of debt that is handed down to future generations and the ecological legacy of pollution and environmental degradation.

The importance of life implies that all people have an inalienable right to the means necessary for subsistence, because this is a fundamental prerequisite for a dignified life. All persons ought to have access to basic resources such as food, water, clothing, shelter and medicine that are necessary to preserve health. Commenting on the relationship between freedom and subsistence rights, Pipes (1999) states:

The symbiotic relationship between property and freedom does not preclude the state from imposing reasonable restraints on the uses made of objects owned, or ensuring the basic living standards of the neediest strata of the population. Clearly one cannot allow property rights to serve as a license for ravaging the environment or ignoring the fundamental needs of the unemployed, sick and aged. (p. 20) 
The second important component of dignity is liberty or freedom. Freedom is a gift that God bestows on the human person despite his or her sin. In the Old Testament, the themes of the imago Dei and the covenant are of central importance for human freedom. The imago Dei entails that the human person is appointed by God as his representative; that is, as a free agent with a free will, who can choose, act, multiply, labour and cultivate (cf. Vorster 2010:597; Gn 1:28). The covenant involves the human being as God's partner and child, who is called to be a free follower and co-worker. From a Christian ethical perspective, freedom ought therefore to be seen as an inviolable part of being human. Self-fulfilment, self-realisation and self-expression form the core content of the right to liberty. It requires that all persons are free to order their actions, express themselves and dispose of their possessions as they think fit. The human's innate freedom is, however, not an invitation to license and anarchy, because these do not constitute true freedom, but rather enslave people (cf. Vorster 2010:597). The Christian concept of freedom contains a positive dimension in the sense that the freedom of the individual must correlate with the freedom of the community. Genesis 1:27 relates the imago Dei to the human's existence as men and women, thereby emphasising the social character of human existence. In the same way that God has the ability to deliberate within the 'self' of the Godhead; that is, to be singular and yet at the same time plural, the human being is created singular as a human being that shares a common humanity, but plural as men and women, sharing a common identity. Likeness, to God, can consequently not be lived in isolation. Inter-human communication, the forming of relationships and the ability to love, express and associate are all reflections of the virtues of God (Vorster 2007:369). The covenant also implies that freedom has a communal dimension - there is an important relationship between the covenant and freedom. Braulik (1998:212) importantly notes that the Israelite social order is legitimated in Deuteronomic material in God's liberation of Israel from servitude in Egypt. This can be seen in the introduction to the Decalogue (Dt 5:6). The Decalogue is portrayed in the Pentateuch as the main point of reference in the covenant for the explication of rights and duties (cf. Dt 5:1, 2). It is framed in the form of a set of universal duties towards God and fellow human beings. However, these duties correlate with a set of rights that others cannot obstruct.

Various passages in the Gospels and in the Epistles grounds freedom in the liberating work of Christ and the free outpouring of God's grace. The incarnation of Christ and the cross is repeatedly described as the revelation of divine solidarity with every person whose experience is that of forsakenness and abandonment (cf. Lk 1:70-74; 4:18-20, Rm 5:1-11). The sign of the cross thus opens the possibility of an ethic of compassionate solidarity (Hollenbach 2003:64).

The Gospels and Pauline epistles utilise the theme of the Kingdom to explain the social implications of Christ's liberating work. The term $\beta \alpha \sigma \lambda \varepsilon \varepsilon 1 \alpha$ [kingship, regality, reign, royalty] is a dynamic term that depicts the fact and manner of God's reign (cf. Louw \& Nida 1989:480). The Kingdom is depicted in the
Gospels as both a present and future reality that expresses the cosmological range of Christ's dominion. The Kingdom of God has come in the person of Christ, but will only be fully realised with the parousia (cf. Mt 19:28; 25:31-36; Mk 1:15; Lk 22:18). In the coming of the Kingdom, God reinstates his glory on earth, renews humanity and transforms his creation. Ephesians 1:20-23 and Colossians 2:15-20 portray Christ as the Kurios who not only reigns over the Church but also the cosmos. All powers are therefore subject to God's reign. Romans 13:1-7 is part of larger paranetic segment that calls on believers to obey the state. They must do so, not because the power of the state is absolute, but because all authority comes from God. The task of the state is enframed in verses 4-6 with

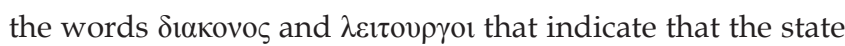
is a servant of God. From the Pauline use of the theme of the Kingdom, we can deduce that Christ's dominion should not exclusively be understood in a soteriological sense, but also in a holistic cosmological sense, not only as a future eschatological reality, but also as a present actuality that has political significance. As a present reality, the Kingdom relativises all earthly power. Christ's expiatory work frees the individual from any ultimate claims on his life by society or the state.

In the Gospels, the gospel of the Kingdom is qualified in various passages as the gospel of the poor (Mt 11:5; Lk 4:18; 7:22). According to Ridderbos (1950:170), the poor refers to the socially oppressed who experience injustice from those who enrich themselves. They long for God's liberation and place all their hope for deliverance in God. They are therefore the true bearers of God's promises. True subjection to God's reign means that the faithful must care for the physically handicapped and the hungry. Insofar as they care for the poor, they care for Christ himself (Mt 25:34-36). Freedom is therefore never an end in itself, but is co-determined by the will of God and the interests of fellow human beings and is thus always exercised within the framework of justice. Seen from a Christian perspective, freedom is an inviolable characteristic of being human and therefore basic liberties must be taken for granted and are not subject to political bargaining or the calculus of social interests. However, Rawls (1993:134) is correct when he states that it is not a requirement for a just society that all basic freedoms should be equally provided for. Rather, freedoms should be adjusted when they clash with each other, so as to provide one coherent scheme equally shared by all members of society. The positive dimension of freedom implies that the rights of individuals and of communities are related concepts and must be balanced in a way that does not violate the dignity of the individual or the community (cf. Vorster 2010:600). The individual is never the mere bearer of interests and intentions, but is always part of an interwoven structure of relationships and responsibilities (Vogel et al. 2007:28).

Equality is, in essence, therefore a status that God grants people, not an inherent characteristic of the human being. Because all people are created in the image of God, all people are alike in dignity (Ps 8). This equality in dignity ought to be maintained, regardless of membership of particular groups 
and regardless of individual or differentiated differences. The Old Testament understands the notion of equality within the realm of justice. The prophets from the eighth century BC attributed the deterioration of social values and the oppression of the poor to the absence of justice. In Deuteronomic and prophetic literature, the liberation from Egypt forms the basis for the fundamental equality amongst the Israelites (cf. Gosai 1993:54, 69). Israel's recollection of its own bondage in Egypt had to prevent them from imposing radical inequality on other racial groups or aliens. The basic structure of Israelite society had to be ordered in such a way that the interests of the weak were cared for. It is a recurring admonition in the Old Testament that the unfortunate must be given their dues, precisely because they have no other rights than what they have in the Lord (cf. Dt 24:17; Am 4:1). The theological reasoning behind this concern for the poor and weak is that inequality leads to bondage and that it therefore is an affront to freedom.

As a result of the secular political environment within which the early Christians lived, the notion of equality mainly surfaces in the New Testament on a soteriological and ecclesiological level. Christ is seen as the origin of the equality between believers. Through his expiatory work he justifies and liberates sinners who do not deserve the grace of God and, in so doing, he makes them children of God ( $\operatorname{Rm} 3: 21-25)$. Love is depicted as the most important instrument of God's justice. Without love there can be no justice, whereas true love will always be an instrument of justice (cf. Du Toit 1991:446). Love extends to all of humanity (cf. Mt 5:44). Its content is defined as 'treating others as you want yourself to be treated' (Mk 12:30, 31). Equal treatment seems to be a defining characteristic of a biblical understanding of equality; yet, equality also demands the breakdown of social barriers. Christ's liberating work creates a priesthood before God that transcends differences of culture, economy and gender (G1 3:28). The faithful's reconciliation with God naturally leads to new relationships with fellow human beings. The undeserved grace of God urges the faithful not to exalt themselves at the expense of others, but to respect each other and serve each other in humility as Christ has done for humankind (Phlp 2:5-7). Paul states explicitly that the boundaries between Jew and Greek, slave and freeman, man and woman are transcended in Christ (Gl 3:28). He also applies the principle of unity in Christ and equality before God to relations between parents and children, masters and slaves (Eph 6:1-9).

From a Christian perspective, we might state that the term equality implies that a person or persons are alike in one or more respects. The most basic respect with regard to which people should all be treated alike is dignity. Equal dignity entails that the power and jurisdiction that people have over each other is reciprocal and mutual. It is thus closely related to justice, which involves people being entitled to the protection of their property, to fair treatment and a fair distribution of goods. Equality is, in essence, a positive kind of freedom and often goes in tandem with liberty. Without certain freedoms people cannot be treated as equal in dignity. Conversely, if people are not treated with equal respect, freedom is compromised. Equality of opportunity and equality before the law, for example, are not only compatible with freedom, but absolutely essential to it.

\section{The specific contribution of a Christian concept of dignity, equality and freedom to rights discourse}

The Christian understanding of human dignity differs from the classic-liberal view in that it is not only understood on the basis of specific traits, skills or achievements, differing as they do from one individual to another, but is also in accordance with the relational structure into which the human is born (Vogel et al. 2007:16). Christianity does not erect a wall of separation between different dimensions of human life, but establishes a connection between them that suggests their necessary and organic unity. The specific contribution that a Christian concept can make to human rights discourse lies therein that it does not isolate the different dimensions of human life from each other, but continuously attempts to correlate the negative and positive dimension of rights and the individual and communal dimensions of human life with each other. The Christian view of human rights is embedded in a wider view of ethics and thus can provide appropriate limits to dignity.

When we translate a theological concept of human dignity into concrete rights language, we might state that human dignity implies respect for the equal autonomy of each person and the right not to be devalued or treated in a degrading or unjust manner. Human dignity does not reside within the individual, but expresses a normative status that is imparted to every human being, regardless of origin, capability, success, gender or race. It does so in a way that human beings, rather than being separated from each other, are thereby bound together (Vogel et al. 2007:17). Because the entitlement to respect is inviolable and not left to arbitrary decisions of others, it is the duty of the state to respect this entitlement and to protect it where it is threatened (Vogel et al. 2007:17). Human dignity not only serves individual interests but also communal interests, in that it circumscribes the most basic circumstances within which people ought to develop and participate fully as members of society. Because dignity is a foundational concept, it informs all the rights of human beings.

The three most important components of dignity are the right to life, which is the source of human dignity, the right to freedom, which derives from the close relationship between dignity and autonomy (cf. in this regard Ferreira $v$ Levin no and others and Vrijenhoek and others $v$ Powell and others [1996:49]) and the right to equality, which is based on the equal dignity of all people and closely resembles justice. Dignity thus invokes equality as well as liberty. Equality addresses systemic injustice and emphasises the dignity of all people regardless of status and class, whilst freedom ensures that each individual can realise his or her potential by safeguarding self-determination under equal circumstances. 
How can human dignity be utilised to reconcile differences between equality and freedom? From a Christian perspective, life is the core component of dignity, whilst liberty and equality are elaborations of the status of dignity that God imparts to all people. Freedom and equality thus possess various dimensions that correspond in a lesser or larger degree to dignity. A right can only be regarded as legitimate when the various components of dignity are at stake and intersect with each other. There exists, for example, no such thing as a right that has implications only for equality, but not for freedom and dignity. Furthermore, most rights are not absolute. Those dimensions of equality and freedom that are essential to dignity always ought to enjoy preference with respect to the non-essential elements. When conflicts of interests arise, the essential elements ought to enjoy preferential treatment. Dignity inhibits equality when a differential act intrudes the inner sanctum or private space of a person to such a degree that his or her equal worth is compromised. Such actions are illegitimate intrusions of personal freedom. Conversely, when the exercise of a freedom impairs the fundamental and equal worth of a person or group of people, it is harmful and not legitimate. The freedom dimension of dignity is therefore a caveat against collectivism and egalitarianism that allows no difference, whilst the equality dimension of dignity is a caveat against social Darwinism that shows no respect for the rights of the 'vulnerable'.

'Dignified freedom' contains a dimension of equal respect for all, whilst 'dignified equality' respects the exercise of liberties. Stated differently, dignified freedom will exercise liberties in a way that is not at the expense of others, whilst dignified equality will not impose sameness or uniformity on all, but will rather attempt to create equal opportunities for all on the basis of non-discrimination. Equality in outcome, in contrast, is not a valid concept, because it is coercive and does not intersect with freedom or dignity. Equality is rather about justice and fairness that requires not only that human beings should not be subjected to unfair discrimination, but also that freedoms should be equally distributed through a fair equality of opportunity (cf. Rawls 1971:73).

\section{Conclusion}

This article states that the classic-liberal view of human dignity creates some interpretative difficulties. The main problem is that human dignity cannot be grounded on purely immanent considerations. It is a transcendental concept and must be acknowledged as such. The classic-liberal view of human dignity grounded in mere humanity, invariable traits of human beings such as autonomy and the reasonable ability to claim rights, do not provide a proper ambit to dignity and thus lead to illegitimate and superficial rights claims. The Christian understanding of human dignity differs from the classic-liberal view in that it regards dignity as an imparted gift to all people that must be realised in accordance with the relational structure into which the human is born. Christianity thus understands human dignity from the perspective of the organic unity of all the different dimensions of human life. In accordance with this premise, the proposal of this article is that life forms the core component of dignity, whilst equality and freedom are elaborations of dignity. Rights claims will only be valid when they contain essential features of all of these elaborations of dignity. Freedom and equality narrows the ambit of dignity, dignity and freedom serve as caveats against egalitarianism and collectivism and dignity and equality protects society against Social Darwinism.

\section{Acknowledgements Competing interests}

The author declares that he has no financial or personal relationships which may have inappropriately influenced him in writing this paper.

\section{References}

Anderson, B.W., 1994, From creation to new creation. Old Testament perspectives, Fortress, Minneapolis, MI.

Braulik, G., 1998, 'Deuteronomy and human rights', Skrif en Kerk 19(2), 207-228.

Chaskalson, A., 2000, 'Human dignity as a foundational value of our constitutional order', South African Journal of Human Rights 16(2), 193-205.

Du Toit, D., 1991, “n Christelike beskouing van mensregte', In die Skriflig 25(4), 439-456.

Ferreira v. Levin NO and Others and Vrijenhoek and Others v. Powell NO and Others, 1996, SA 984 (CC).

Gosai, H., 1993, Justice, righteousness and the social critique of the eighth century prophets, series vii: Theology and religion, Peter, New York, NY.

Harland, P.J., 1996, The value of human life. A study of the story of the flood. Genesis 6-9, Brill, Leiden.

Hollenbach, D., 2003, The global face of public faith. Politics, human rights and Christian ethics, Georgetown University, Washington, DC.

Louw, J.P. \& Nida, E.A., 1989, Greek-English lexicon of the New Testament based on semantic domains, vols. 1-2, United Bible Societies, New York, NY.

Milbank, J., 2006, Theology and social theory. Beyond secular reason, 2nd edn., Blackwell, Malden.

O' Donovan, J.L., 2010, 'Human dignity and human justice in theological perspective', in P.M. Candler \& C. Cunningham (eds.), The grandeur of reason, pp. 118-135, SCM Press, London.

Otto, E., 1999, 'Menschenrechte im alten Orient und im Alten Testament', in Theologie Online, viewed 24 May 2012, from http://www.theologie-online.uni-goettingen. de/at/otto.htm

Otto, E., 2002, Gottes recht als Menschenrecht. Rechts und Literaturhistorische Studien zum Deuteronomium, Beihefte zur Zeitschrift für Altorientalische und Biblische Rechtgeschichte, vol. 2, Harrassowitch Verlag, Wiesbaden.

Pipes, R., 1999, 'Life, liberty and property', Commentary 107, 17-21.

Rawls, J., 1971, A theory of justice, rev. edn., Belknap Press, Cambridge, MA.

Rawls, J., 1993, Political liberalism, Columbia University, New York, NY.

Republic of South Africa, 1996, Constitution of the Republic of South Africa, as adopted by the Constitutional Assembly on 8 May 1996 and as amended on 11 October 1996, Government Printers, Pretoria.

Ridderbos, H., 1950, De komst van het koninkrijk, Kok, Kampen.

Stackhouse, M., 2006, 'Why human rights needs God: A Christian perspective', in E.M. Bucar \& B. Barnet (eds.), Does human rights need God, pp. 25-41, Eerdmans, Grand Rapids, MI.

Van der Ven, H.A, Dreyer, J.S. \& Pieterse, H.J.C., 2004, Is there a God of human rights? The complex relationship between human rights and religion. A South African case, Brill, Leiden.

Van Seters, J., 1997, Histiography in the ancient world and the origins of biblical history, Yale University Press, New Haven, CT.

Vogel B., Herms, E., Honecker, M., Mack, E., Ockenfels., W., Nothelle-Wildfeuer, U. et al., 2007, Human dignity. Christian responsibility as a basis for the practice of politics, transl. P. Slotkin, Konrad Adenhauer Stiftung, Berlin.

Vorster, N., 2007, 'The value of human life', Ecumenical Review 59, 363-384. http:// dx.doi.org/10.1111/j.1758-6623.2007.tb00638.x

Vorster, N., 2010, 'Are freedom and equality natural enemies', The Heythrop Journal. A Bimonthly Review of Philosophy and Theology 51, 594-610.

Witte, J., 2006, God's joust, God's justice. Law and religion in the Western tradition, Eerdmans, Grand Rapids, MI. 